\title{
ТРАНСПОРТНА РУХЛИВІСТЬ НАСЕЛЕННЯ НА ПРИКЛАДІ ПЕРЕМІЩЕНЬ ТРАНСПОРТНИМИ КОРИДОРАМИ БІЖЕНЦІВ: ГОСПОДАРСЬКО-ПРАВОВІ ВИКЛИКИ ПІД ЧАС COVID-19 ЧИ МІГРАЦІЙНА КРИЗА ХХІ СТОЛІТТЯ?
}

Лавренюк Н. С.

Статтю присвячено розгляду окремого виду транспортної рухомості населення - переміщення транспортними коридорами біженців, адже визначення динаміки перерозподілу рухливості населення, а саме біженців, є актуальною проблемою організації роботи транспортних систем. Доведено, що COVID-19 несе низку додаткових господарсько-правових викликів до наявної міграційної кризи XXI століття, схожу на міграційну кризу 2015 року. Встановлено, що важелями виходу із кризової ситуації $\epsilon$ спільно направлена міграційна політика та низка законодавчих інічіатив, які стосуються побудови належної системи регулювання при буття та розміщення, а також перебування біженців у країнах притулку. Вперше було запропоновано господарсько-правове рішення щодо усунення проблеми скупчення біженців у транспортних коридорах - прийняття Закону «Про тюремне покарання мігрантів, біженців та переміщених осіб за незаконний перетин кордону під час коронавірусу COVID-19», в якому покаранням за перетин транспортних коридорів в умовах надзвичайного стану під час COVID-19 будуть громадсько-виправні роботи в колоніях.

Ключові слова: міграція, транспортні шляхи, логістика, транспортна система, транспортна інфраструктура, мобільність, пандемія.

Статья посвящена изучению отдельного вида транспортной подвижности населения - перемещению транспортными коридорами беженцев, ведь определение динамики перераспределения подвижности населения, а именно беженцев, является актуальной проблемой организации работы транспортных систем. Доказано, что COVID-19 привносит ряд дополнительных хозяйственно-правовых вызовов в существующий миграционный кризис XXI века, схожий на миграционный кризис 2015 года. Установлено, что рычагами выхода из кризисной ситуации являются совместно направленная миграционная политика и ряд законодательных инициатив, касающихся построения надлежащей системы регулирования прибытия и размещения, а также пребывания беженцев в странах убежища. Впервые было предложено хозяйственно-правовое решение относительно устранения проблемы скопления беженцев в транспортных коридорах - принятие Закона «О тюремном наказании мигрантов, беженцев и перемещенных лиц за незаконное пересечение границы во время коронавируса COVID-19", в котором наказанием за пересечение транспортных коридоров в условиях чрезвычайного положения во время COVID-19 будут общественно-исправительные работы в колониях.

Ключевые слова: миграция, транспортные пути, логистика, транспортная система, транспортная инфраструктура, мобильность, пандемия.

(с) Лавренюк Н. С., 2020
Lavreniuk N. S. Travel behavior of the population in terms of movement on transport corridors of the refugees: economic and legal challenges during COVID-19 or the migration crisis of the 21st century?

The article is devoted to the consideration of a separate type of transport mobility of the population - the movement transport corridors for refugees because the definition of redistribution dynamics of the mobility of the population, namely refugees is an actual problem of the organization of work of transport systems. In the course of the study, the author set certain restrictions for focusing on the subject of research, namely: the psychological profile of refugees, demographic and any other statistical indicators, the purpose and method of movement, speed and frequency, seasonality and external factors. It is determined that in this article only the economic and legal consequences of the movement of refugees by transport routes in the context of a pandemic are important. Attention is drawn to the fact that in the integration process of the refugee movement transport corridors brings many challenges for all countries at the political and economic level, ending unresolved on the legislative level. The choice of economic and legal dimension for a comprehensive consideration of the movement of refugees through transport corridors is justified by the fact that economic law conglomerates public and private interests through the available legal tools. It is proved that COVID-19 carries a number of additional economic and legal challenges in the current migration crisis of the XXI century similar to the migration crisis of 2015. It is established that the lever to overcome the crisis situation is: jointly directed migration policy and a number of legislative initiatives related to the construction of an appropriate system for regulating the arrival and placement, as well as the stay of refugees in countries of asylum. The reasons why countries should not avoid the responsibility of not accepting the flow of migrants are justified on the example of the actions of the authorities of Poland, Hungary and the Czech Republic in 2015. For the first time, an economic and legal solution was proposed to eliminate the problem of accumulation of refugees in transport corridors - to adopt the Law "On prison punishment of migrants, refugees and displaced persons for illegal border crossing during coronavirus COVID-19" in which the punishment for crossing transport corridors in a state of emergency during COVID-19 is social correctional work in colonies.

Key words: migration, transport routes, logistics, transport system, transport infrastructure, mobility, pandemic.

Постановка проблеми та їі актуальність. В євроінтеграційних умовах української економіки в цілому та транспортної системи зокрема йдеться про транзитну міграцію товарів, послуг і населення - надважливої тріади європейських цінностей, до яких спрямована українська доктрина. При цьому не викликає заперечень той факт, що в житті практично кожної людини важливе значення мають житло, місце роботи, освіта, культурно-побутові та просвітні потреби, відпочинок. 
Проте реалізувати всі ці функції в одному місці зараз не $\epsilon$ можливим, що породжує потребу в пересуванні. Крім того, потреба населення в пересуваннях визначається рівнем розвитку суспільства, його соціальною структурою, рівнем розвитку суспільного виробництва, сформованим укладом життя, характером розселення тощо. Однак сам процес пересування відбувається динамічно з огляду на зростання попиту власних інтересів та неможливості їх реалізації без зміни геолокації. Тож, визначення динаміки перерозподілу рухливості населення, а саме біженців, $\epsilon$ актуальною проблемою організації роботи транспортних систем.

Аналіз останніх досліджень і публікацій. Відзначимо наш науково-практичний інтерес до транспортних коридорів (див. [1]). Також відмітимо, що окремі аспекти транспортної рухливості населення були досліджені такими авторами, як: В.К. Доля, І.Є. Іванов, J. Mattson, L. Frändberg, B. Vilhelmson, J.P. Bocarejo S., D.R. Oviedo, H.S. Kim та інші. Підкреслимо, що транспортну рухливість населення частіше розглядають із технічної сторони, що ніби нівелює їі актуальність із правової. Тож, пересування транспортними коридорами $\epsilon$ малодослідженим і перспективно новим напрямом у правовій науці загалом і господарському праві зокрема.

Мета статті - на підставі наявних наукових доробок із проблематики транспортної рухливості населення 3'ясувати іï особливості стосовно переміщення транспортними коридорами біженців з господарсько-правової призми розгляду в умовах пандемії та міграційної кризи XXI століття.

Виклад основного матеріалу. Транспорт $\epsilon$ однією з найважливіших інфраструктурних галузей матеріального виробництва, яка забезпечує потреби в усіх видах перевезень. Розвиток та діяльність транспортної сфери відбуваються в органічній єдності з розвитком та діяльністю виробничої сфери цього ж виду діяльності в регіоні. Природні, екологічні, соціальні та економічні чинники часто визначають зміст параметрів транспортного забезпечення і $є$ вирішальними на даній території. При цьому якість транспортного забезпечення визначає рівень фінансових затрат та економічний стан конкретного регіону [2, с. 32]. Тож, транспортний комплекс країни $є$ унікальним з точки зору вирішення загальногосподарських завдань, а також за чисельністю залучених трудових ресурсів, що взаємопов'язує всі галузі народного господарства [3, с. 18].

Компактність території, сприятливі природно-географічні умови, значний потенціал транзитності, висока транспортна доступність усіх регіонів, наявність міжнародних транспортних коридорів [4, с. 53] - головні чинники сприятливого ведення транспортно-логістичної діяльності для будь-якої держави, які $€$ визначальними для переміщення.

Зазначимо, що дослідження мобільності містян - це «сукупність видів діяльності, за допомогою яких збирається соціально-економічна інформація про основні складники рухливості міського населення. Його метою $\epsilon$ одержання вихідних даних для планування, проектування і модернізації вулиць і доріг, а також для проекту покращення експлуатаційних режимів на наявній вулично-дорожній мережі з урахуванням безпеки, неперервності, зручності, економічності транспортного та пішохідного руху» [5, с. 409]. Тобто нас цікавитиме мобільність біженців задля одержання необ- хідної інформації про стан та перспективи покращення функціональності транспортних коридорів у господарсько-правовому вимірі.

Задля вирішення сформованої вище мети існують різні підходи щодо визначення рухливості населення. Традиційним показником рухливості населення $\epsilon$ кількість поїздок, що припадає на одного жителя на рік. 3 іншої точки зору - це кількість пасажиро-кілометрів, що припадає на одного жителя теж на рік. Слід відмітити, що для повної характеристики рухливості слід використовувати обидва підходи. Крім того, рухливість необхідно визначати для кожного виду транспорту, а також - окремо для дальнього, внутрішньоміського, міжміського і приміського сполучення [6, с. 27].

Обсяг перевезень вимірюється числом планових або фактично перевезених пасажирів. Вихідною інформацією $€$ транспортна рухомість населення. Вона може бути визначена для країни, області або міста як сумарне число поїздок населення протягом року, віднесене до всієї чисельності проживаючих у них жителів. Переміщення людей пов'язані з їхньою життєдіяльністю. У конкретних соціально-історичних та економічних обставинах потреба в переміщеннях визначає рівень розвитку продуктивних сил, суспільного виробництва, соціальну структуру суспільства. Інтенсивність переміщень кількісно виражається показником рухомості населення. Розрізняють поняття потенційної, реалізованої, абсолютної, загальної, пішохідної та транспортної рухомості. У загальному випадку під рухомістю розуміють кількість переміщень, що приходяться на одну людину із розглядуваної групи за той чи інший розрахунковий період часу [7, с. 156].

Натомість предметом розгляду нашого дослідження $\epsilon$ не все населення всього світу, а лише його певна соціальна група - біженці. Крім того, варто розтлумачити поняття «переміщення транспортними коридорами біженців».

Нагадаємо, що переміщення - це безпечне пересування особи з одного місця знаходження до іншого або перехід з однієї позиції в іншу.

Загальновідомо, що майже кожне поняття можна розглянути з вузького й широкого підходів. Тож, безумовно, концепт «транспортний коридор» $\epsilon$ багатогранним з огляду на те, з якої грані підходу його детально розглядати. Так, безперечно, цей концепт набув широкого використання в географії. Проте праворозуміння в юридичній сфері $\epsilon$ ширшим. Візьмемо до уваги «Пан'європейський міжнародний транспортний коридор» [1], або «міжнародний водний шлях E-40» [8], чи «Морський Шовковий Шлях» [8]. Але нас цікавлять транспортні коридори, якими пересуваються біженці.

Відповідно до універсального в міжнародному праві визначення поняття «біженець», закріпленого в Конвенції Організації Об'єднаних Націй про статус біженців (1951 р.), під біженцем розуміється «особа, яка через обґрунтовані побоювання стати жертвою переслідувань за ознакою расової належності, релігії, громадянства, належності до певної соціальної групи чи політичних поглядів знаходиться за межами країни своєї національної належності і не в змозі користуватися захистом цієї країни або не бажає користуватися таким захистом унаслідок таких побоювань; або, не маючи визначеного громадянства і знаходячись за межами країни свого колишнього місця проживання в результаті подібних 
подій, не може чи не бажає повернутися до неї внаслідок таких побоювань» [9, с. 50]. Надалі саме це визначення поняття «біженець» було адаптовано до національного законодавства більшості держав, у тому числі в України шляхом ратифікації відповідного Закону «Про приєднання України до Конвенції про статус біженців і Протоколу щодо статусу біженців» (2002р.).

В інтеграційних процесах переміщення біженців транспортними коридорами несе безліч викликів для всіх країн світу на політико-економічному рівні, закінчуючи неврегульованістю на законодавчому рівні. Вибір саме господарсько-правового виміру для всебічного розгляду означеної проблеми визначається тим, що господарське право конгломерує публічні й приватні інтереси шляхом наявного правового інструментарію.

Підкреслимо, що не $\epsilon$ предметом розгляду цієї статті психологічний портрет біженців, демографічні й будь-які інші статистичні показники, мета й спосіб пересування, швидкість і частота, сезонність і зовнішні чинники. Важливими $\epsilon$ лише господарсько-правові наслідки пересування біженців транспортними шляхами в умовах пандемії.

Щоразу більша кількість біженців перетинає європейські кордони в пошуках кращого життя, що стало загрожувати безпеці та стабільності європейських країн та спричинило кризові явища в європейському середовищі [10, с. 337]. Проблеми біженців та шукачів притулку сьогодні $є$ проблемами глобального масштабу, оскільки вони виходять далеко за межі географічних регіонів та зв'язують потоками людських ресурсів різні країни та регіони світу [11, с. 103]. Візьмемо до уваги критичну ситуацію на кордонах Туреччини й Греції. Попри те, що грецькі патрулі контролюють всю прибережну зону, намагаючись не допустити проникнення в країну нелегальних біженців, потік тих, хто прагне до кордону з Грецією і Туреччини, щоб потрапити на територію ЄС, зростає. Біженці використовують шлях через річку Еврос, яку перетинають на гумових човнах. При цьому ситуація з наявною світовою пандемією COVID19 лише якоюсь мірою проявила наявну кризу міжнародного захисту прав людини. Так, зокрема, закриття портів у Італії та Мальті у зв'язку з коронавірусом зараз не дозволяє рятівним човнам громадських організацій, які підбирають мігрантів, висадити їх на берег. Крім того, Франція, Німеччина, Італія та Іспанія закликають Єврокомісію підтримати «механізм пошуку та солідарності» щодо мігрантів, які прибувають через Середземне море.

У зв'язку з наведеним можемо припустити, що COVID-19 несе низку додаткових господарсько-правових викликів до наявної кризи XXI століття. Наразі країни практично всього світу зіткнулися із ситуацією, схожою на міграційну кризу 2015 року. Натомість важелями виходу з кризової ситуації $€$ спільно направлена міграційна політика та низка законодавчих ініціатив, які стосуються побудови належної системи регулювання прибуття та розміщення, а також перебування біженців у країнах притулку.

Нагадаємо, що міграційна політика в загальному розумінні $\epsilon$ «системою спеціальних національних законів, а також міграційних угод з регулювання міграційних потоків, обмеження припливу або відтоку біженців і нелегалів і стимулювання припливу економічно ефективного людського капіталу, насамперед наукових кадрів і висококваліфікованих фахівців різних галузей» [12, с. 55]. Загальновідомо, що міжнародна міграція виникає за наявності великого контрасту між рівнями економічного розвитку і темпами природного приросту країн-донорів та країн-реципієнтів робочої сили. Історично склалося так, що ядром міграційної політики було дотримання прав людини на можливість вільного пересування, що знайшло підкріплення в багатьох європейських нормативно-правових актах та угодах, укладених міжнародними організаціями.

Можемо погодитися з думкою В.В. Євдокимова, що «у випадку побудови належної системи регулювання прибуття та розміщення, а також перебування біженців у країнах притулку, вони можуть створювати і ряд позитивних моментів, поповнюючи ринок робочої сили, що сприяло б економічному зростанню через здешевлення трудових ресурсів, заповненню низових ніш ринку праці» [11, с. 102]. У зв'язку з цим необхідно прийняти універсальне правове рішення щодо біженців.

Пропонуємо таке господарсько-правове рішення щодо усунення проблеми скупчення біженців у транспортних коридорах - прийняти Закон «Про тюремне покарання мігрантів, біженців та переміщених осіб за незаконний перетин кордону під час коронавірусу COVID-19», в якому покаранням за перетин транспортних коридорів в умовах надзвичайного стану під час COVID-19 будуть громадсько-виправні роботи в колоніях. При цьому не слід проводити паралелі з прийнятим в Угорщині законодавчим пакетом «Стоп Сорос». Також необхідно зауважити, що країнам не слід уникати відповідальності, не приймаючи потік біженців, адже у квітні цього року Суд ЄС виніс рішення щодо дій влади Польщі, Угорщини й Чехії у 2015 році, які, намагаючись уникнути транзиту нелегальних мігрантів, тим самим порушили зобов'язання за договором про Європейський Союз.

Висновки. COVID-19 не $\epsilon$ першопричиною міграційної кризи XXI століття, що свідчить про необхідність моментального, але виваженого реагування від країн усього світу. Практика дій влади Польщі, Угорщини й Чехії свідчить про настання негативних юридичних наслідків через ухилення від відповідальності. Тож, зваженим рішенням для зменшення потоку біженців у транспортних коридорах має бути оптимальна міграційна політика та дотримання норм запропонованого нами закону.

Перспективами подальших досліджень вбачаємо розгляд методів розрахунків кількості переміщень транспортними коридорами біженців та 3'ясування їхніх особливостей, покращення пропускної здатності транспортних коридорів; окремого розгляду потребують оцінка ризиків переміщення транспортними коридорами біженців і безпека транспортних коридорів і біженців під час перетину транспортних коридорів.

\section{Література}

1. Lavrenyuk N.S. Eurologistics of transport corridors in EU integration processes and transport networks. Slovak international scientific journal. 2020. № 39. Vol. 3. P. 60-63.

2. Кучменко В.О. Удосконалення механізму управління транспортною системою міста : дис. ... на здобуття наукового ступеня кандидата економічних наук : 08.00.05 «Розвиток продуктивних сил та регіональна економіка» ; Східноукраїнський національний університет імені Володимира Даля. Сєвєродонецьк, 2018. 218 с. 


\section{Проблеми цивільного та господарського права}

3. Карпінський Б., Макух Б. Транспортна система України в контексті європейської інтеграції. Економіка України. 2008. № 7 (440). С. 17-23.

4. Бойко 3. Територіальна структура та регіональні особливості залізничного транспорту України. Наукові записки. 2017. № 1. С. 49-55.

5. Осетрін М.М. Дослідження попиту і пропозиції мобільності міського населення на прикладі м. Ужгород. Містобудування та територіальне планування. 2018. Вип. 68. С. 409-419.

6. Кристопчук М.Є., Любашов О.О. Приміські пасажирські перевезення : навчальний посібник. Харків : HTMT, 2012. 224 C.

7. Веснін А.В. Аналіз моделей транспортної рухливості населення. Вісник Криворізького національного універсuтету. 2012. Вип. 32. С. 155-159.

8. Слатвінська В. Можливості для внутрішніх водних шляхів України або перспективи впровадження E-40 для України шляхом об'єднання Чорного й Балтійського морів. Юридичний вісник. 2019. № 3. С. 169-174.
9. Свящук А.Л. Проблеми прав біженців та виклики сучасності : навч. посіб. Харків : Вид-во, 2018. 324 с.

10. Алгаш В., Піттель А. Сучасна міграційна криза як виклик для Європейського Союзу. Підприємництво, господарство і право. 2019. № 2. С. 334-338.

11. Євдокимов В.В., Шиманська К.В. Навантаження біженців на країни та території при формуванні політики щодо біженців та шукачів притулку. Вісник ЖДТУ. 2018. № 4 (86). C. 96-104.

12. Пак Н.А. Міграційна політика Європейського Союзу: проблеми і перспективи. Вісник Харківського Національного університету імені В.Н. Каразіна. 2017. Вип. 6. С. 54-57.

Лавренюк Н. С., аспірантка кафедри господарського права і процесу Національного університету «Одеська юридична академія" ORCID 0000-0001-8946-3252 